\title{
学校健診における言語障害検診の重要性
}

\author{
森実 加奈 ${ }^{1)}$ 佐藤 公美 ${ }^{1)}$ 三根生 茜 ${ }^{1)}$ 合田 侑以 ${ }^{1)}$ \\ 長嶋比奈美 ${ }^{1)}$ 宇高 二良 ${ }^{1)}$ 武田 憲昭 ${ }^{2}$
}

\begin{abstract}
要 約 : 就学時健診の 231 児に対して, 耳鼻咽喉科医による「学校保健での音声言語障害の 検診法」を用いた言語障害の検診，言語聴覚士による事前の言語スクリーニングおよび言語障 害と診断された览の言語の精密検査を実施した。医師による言語障害の検診にて言語異常の所 見ありと診断されたのは，31 児であった。一方，言語聴覚士による事前の言語スクリーニン グにて言語異常の所見ありと評価された児は 47 名であり, 異常の所見なしと評価された児の なかで，医師が検診で言語障害と診断した児はなかった。精密検査を実施した 14 児のうち, 異常なしと診断されたのは 1 児のみであり, 他の 13 児は言語訓練が必要であった。健診で医 師が「学校保健での音声言語障害の検診法」を活用するためには, 言語聴覚士による事前の言 語スクリーニングが有用であり，言語障害の検診を適切に実施すれば，それまでに診断されて いなかった言語障害児を発見して言語訓練の機会を与えることができると考えられた。
\end{abstract}

索引用語：学校健診, 言語異常検診, 就学時健診, 言語スクリーニング

\section{The Importance of Language Disorder Screening in School Medical Examinations}

\author{
Kana Morizane $^{1)}$, Kumi Satou ${ }^{1)}$, Akane Mineoi ${ }^{1)}$, Yui Goda ${ }^{1)}$, Hinami Nagashima ${ }^{1)}$, \\ Jiro Udaka ${ }^{1)}$ and Noriaki Takeda ${ }^{2}$
}

\begin{abstract}
Two hundred thirty-one preschool children received language disorder screening in school medical examinations. Pre-screening by speech-language-hearing-therapists found 47 children were suspected to have language disorders, and medical examination by an otolaryngologist led to a diagnosis of language disorder in 31 children. Among children not suspected of having a language disorder during pre-screening, no language disorder was diagnosed. This finding suggests that screening by a speech-language-hearing-therapist before a medical examination is helpful for otolaryngologists to determine language-impaired preschool children. Fourteen language-impaired preschool children found during language disorder screening received a detailed examination, and all except one required language training. This finding suggests that language disorder screening performed properly gives unidentified language-impaired children the opportunity to receive language training.
\end{abstract}

Key words: language disorder, school medical examination, screening, preschool children

宇高耳鼻咽喉科医院 ${ }^{12}$ : $\overline{7} 779-3233$ 徳島県名西郡石井町石井字石井 635-29

徳島大学医学部耳鼻咽喉科 ${ }^{2)}$ : =770-8503 徳島県徳島市蔵本町 3-18-15

${ }^{1)}$ Udaka ENT Clinic: 635-29 Ishii, Myozai-gun, Tokushima 779-3233, Japan

${ }^{2)}$ Department of Otolaryngology, Tokushima University School of Medicine: 3-18-15 Kuramoto, Tokushima 770-8503, Japan 2010 年 9 月 16 日受稿 2010 年 12 月 24 日受理 


\section{はじめに}

学校健診はすべての子供を横断的にスクリーニング できることから，言語障害児を発見できる貴重な機会 であり, 耳鼻咽喉科医が重要な役割を担っている。学 校健診における言語障害の検出には, 日本耳鼻咽喉科 学会学校保健委員会が作成した「学校保健での音声言 語障害の検診法」1,2) が推奨されてきた。この検診法を 用いた場合, たとえば機能性構音障害では小学校低学 年での有所見率が10２0\%と記載されている.しかし， 日本耳鼻咽喉科学会学校保健委員会の定点調査では, 学校健診における言語障害の有所見率はわずか $0.17 \%$ と低( ${ }^{3)}$.このことから, 学校健診において「学校保 健での音声言語障害の検診法」が十分に活用されてお らず, 言語障害が見逃されている可能性が考えられる.

本研究では, 就学時健診において耳鼻咽喉科医が「学 校保健での音声言語障害の検診法」に基づいて言語障 害を診断し，言語障害の有所見率を検討した。同時に， 耳鼻咽喉科医とともに就学時健診に参画した言語聴覚 士が, 健診対象児全例に対し,あらかじめ言語スクリー ニングを実施した。これにより, 耳鼻咽喉科医の検診 前の言語聴覚士による言語スクリーニングの有用性を 検討した，最後に，健診で言語障害と診断された览の うち, 言語の精密検査を実施しえた症例の精査結果を 検討した。

\section{対象および方法}

徳島県の小学校 4 校において, 平成 19 年度就学時 健診を受診した231 児（男 125 児, 女 106 児）を対象 とし, 平成 19 年 10 月から 11 月にかけて健診を行った。 健診には耳鼻咽喉科医とともに 2 名の言語聴覚士が参 画した。全対象児に対し言語聴覚士が言語スクリーニ ングを実施した後, 耳鼻咽喉科医が鏡検的診察と言語 障害の検診を行った。

\section{1 、言語聴覚士による言語スクリーニング}

「ことばのテスト絵本」4) のテスト 3 から, 高頻度語 で目的音 $(\mathrm{k} / \mathrm{g} / \mathrm{s} / \mathrm{ts} / \mathrm{d} z / \mathrm{r})$ が含まれている単語 13 個 (飛行機/学校/スイカ/積木/象/テレビ等) の図を用い て, B4 用紙裏表 1 枚に収まる図版を作成した。言語 聴覚士による言語スクリーニングでは, 被検児全員に この図版を呈示し, 単語を呼称させて誤構音の有無で 構音の評価を行った，次に，「ことばのテスト絵本」) のテスト 4 の「魚釣り」の状況絵を提示し, 順に状況 の説明を指示し, 語彙数ではキーワードである「魚」「釣 る」「落ちる」「助ける」などがすべて出ているか，ま
た応答の仕方では, 吃音の有無に加え, 語頭音の繰り 返し, ブロック, 引き伸ばし, 随伴症状の有無で評価 を行った。

\section{2.耳鼻咽喉科医による検診}

耳鼻咽喉科医は, 被検児全員に対し「就学時の健康 診断マニュアル $\rfloor^{5)}$ に従って鏡検的診察を行いながら, 「学校保健での音声言語障害の検診法」を用いて言語 障害の検診を行った。すなわち，「お名前は？」と問 いかけて被検児より「○○です.」と返答させ,さら に「年は何歳？」，「誕生日は何月何日？」という問い かけを追加した，質問に対する受け答えで何らかの言 語障害が疑われた場合には，「ことばのテスト絵本」4) を用いてテスト 3 の単語絵カードを呼称させたり，テ スト 4 の状況説明絵を呈示し, 語彙数ではキーワード である「魚」「釣る」「落ちる」「助ける」などがす心゙ て出ているか, 会話の流暢性では吃音の有無について 検査した。なお，養護教員から前もって被検児に対し て、「○○です。よろしくおねがいします.」と発話さ せるような指示は行わなかった。

\section{3. 言語異常有所見児の言語の精密検査}

健診で言語異常の所見ありと診断された览の保護者 に対して, 学校より「就学時の健康診断結果のお知ら せ」を送付し, 言語の精密検査を勧告した。 そのうち, 著者らの診療所を受診した児に対して, 構音検査, 純 音聴力検查, 絵画語彙発達検査, WPPSI 知能検査, 随意運動発達検査等の言語の精密検査を行った.

\section{結果}

\section{1 . 検診における言語異常の有所見率}

就学時健診での耳鼻咽喉科医による「学校保健での 音声言語障害の検診法」を用いた言語障害の検診の結 果, 言語異常の所見ありと診断したのは 31 児であり, 有所見率は $13.4 \%$ あ゙った（図 1)。これは, 今回の健 診で診断した耳鼻咽喉科疾病のなかで, アレルギー性 鼻炎の $41.6 \%$ に次いで 2 番目に高い有所見率であっ た。

\section{2. 言語聴覚士による言語スクリーニング}

耳鼻咽喉科医は学校健診という限られた時間内で, 鏡検的診察による耳鼻咽喉科疾病の診断と発話や行動 面から判断する言語障害の診断を行う必要がある。そ のため, 効率良く言語障害を診断するために, あらか じめ言語聴覚士による言語スクリーニングを実施し た、その結果，言語スクリーニングで言語聴覚士が言 語異常の所見ありと評価した览は 46 名(19.9\%)であっ た. 


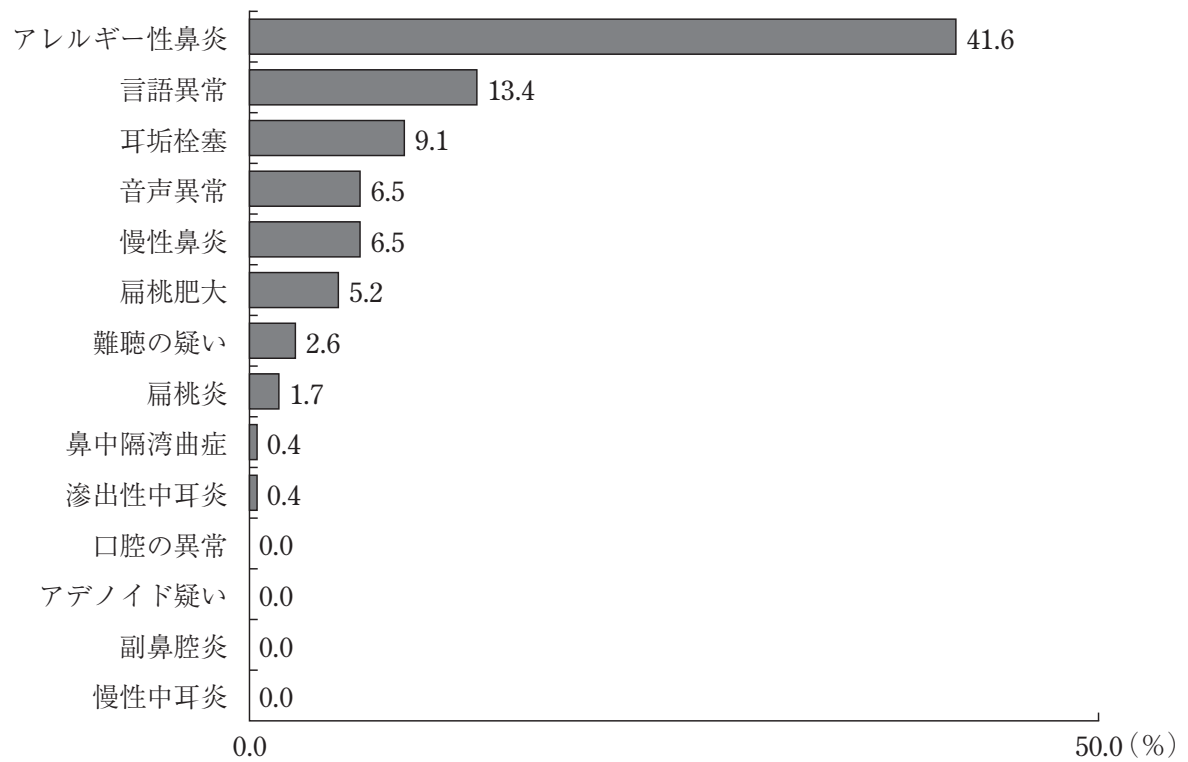

図 1 健診対象児の耳鼻咽喉科疾病の有所見率

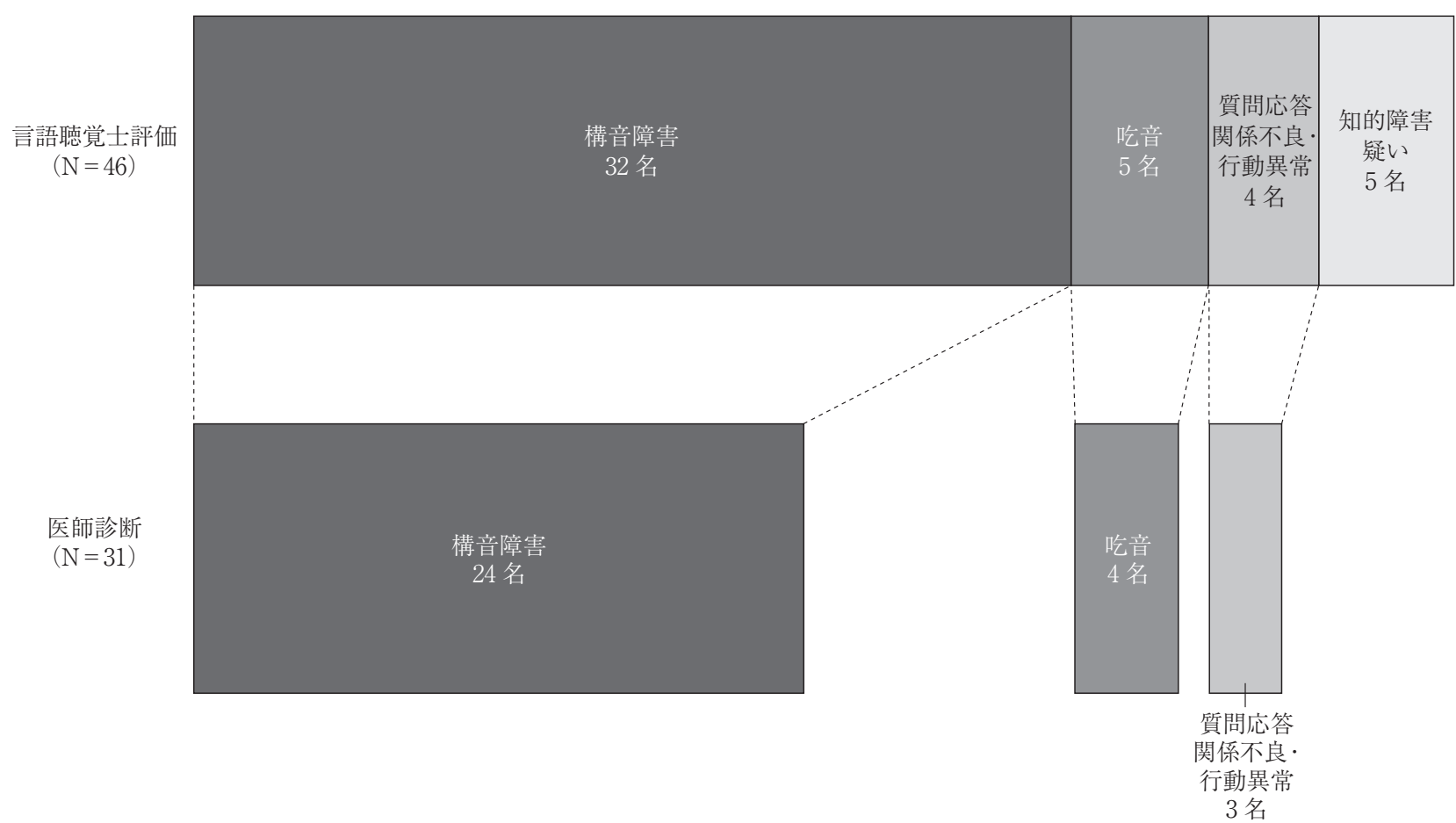

図 2 言語聴覚士による言語スクリーニングと医師の診断

次に，言語聴覚士による事前の言語スクリーニング の結果を検討した。言語聴覚士が構音障害の所見あり と評価した 32 児のうち，医師が構音障害と診断した のは24児であった。言語聴覚士が吃音（5巟），質問 応答関係不良·行動異常 (4 児), 知的障害疑い（5 児） の所見ありと評価した児のうち, 耳鼻咽喉科医が吃音 と診断したのが 4 名，質問応答関係不良・行動異常と 診断したのが 3 名で，知的障害疑いと診断した児はい なかった（図 2)。言語聴覚士が事前の言語スクリー
ニングで言語異常の所見なしと評価した巟のなかで， 医師が検診で言語障害を診断した児はいなかった。

\section{3．言語障害に対する保護者の気づき}

健診で言語障害と診断された 31 児の保護者に言語 の精密検査を勧告し，われわれの診療所を受診したの は 14 児 $(45 \%)$ であった。このうち，7児は今回の 健診で初めて言語障害を指摘された。今回の健診で初 めて言語障害を指摘された 7 监の保護者のうち，3名 は子供の言語異常に気づいておらず，4名は気づいて 
表 1 精密検查施行児一覧

\begin{tabular}{|c|c|c|c|c|c|c|c|c|}
\hline \multirow{2}{*}{ 症例 } & \multirow{2}{*}{ 性別 } & \multirow{2}{*}{$\begin{array}{l}\text { 来院時 } \\
\text { 年齢 }\end{array}$} & \multirow{2}{*}{$\begin{array}{l}\text { 受診の } \\
\text { きっかけ }\end{array}$} & \multirow{2}{*}{$\begin{array}{l}\text { 言語病理学的 } \\
\text { 診断名 }\end{array}$} & \multicolumn{2}{|c|}{ 主な検査結果 } & \multirow{2}{*}{$\begin{array}{l}\text { 保護者の } \\
\text { 気づき }\end{array}$} & \multirow{2}{*}{ 検査歴 } \\
\hline & & & & & WPPSI, PVT, その他 & 構音 & & \\
\hline 1 & M & 6 & 今回の健診 & $\begin{array}{l}\text { 発達障害 } \\
\text { (学習障害) }\end{array}$ & $\begin{array}{l}\text { VIQ } 79, \text { PIQ } 104, \\
\text { IQ } 89 / \text { VA } 5: 10, \text { SS } 8\end{array}$ & & なし & なし \\
\hline 2 & $\mathrm{~F}$ & 6 & 今回の健診 & 機能性構音障害 & VIQ 94, PIQ 107, IQ 101 & $\mathrm{t} / \mathrm{k}$ & なし & なし \\
\hline 3 & M & 6 & 今回の健診 & $\begin{array}{l}\text { 構音障害· } \\
\text { 言語発達遅滞 }\end{array}$ & $\begin{array}{l}\text { VIQ 89, PIQ 87, IQ 86/VA 5:9, } \\
\text { SS } 8\end{array}$ & $\mathrm{t} / \mathrm{k}, \mathrm{t} / \mathrm{g}$ & あり & なし \\
\hline 4 & M & 6 & 今回の健診 & $\begin{array}{l}\text { 構音障害· } \\
\text { 言語発達遅滞 }\end{array}$ & $\begin{array}{l}\text { VIQ 93, PIQ } 103 \\
\text { IQ } 97 / \text { VA } 5: 3, \text { SS } 7\end{array}$ & $\begin{array}{l}\mathrm{t} / \mathrm{k}, \quad \mathrm{t} \int / \mathrm{k}, \quad \int / \mathrm{s}, \quad \mathrm{d} z / \mathrm{dz}, \\
\mathrm{d} / \mathrm{r}\end{array}$ & あり & なし \\
\hline 5 & M & 6 & 今回の健診 & 知的障害 & $\begin{array}{l}\text { VIQ 63, PIQ } 78, \\
\text { IQ } 64 / \text { VA } 3: 10, \text { SS } 2\end{array}$ & & あり & なし \\
\hline 6 & $\mathrm{~F}$ & 6 & 今回の健診 & $\begin{array}{l}\text { 構音障害· } \\
\text { 言語発達遅滞 }\end{array}$ & $\begin{array}{l}\text { VIQ 67, PIQ 94, IQ 76/VA 4:6, } \\
\text { SS } 4\end{array}$ & $\mathrm{t} \int / \mathrm{s}, \mathrm{ts} / \mathrm{s}$ & あり & なし \\
\hline 7 & $\mathrm{~F}$ & 6 & 今回の健診 & 異常なし & VA $6: 1, \quad S S 9 * 1$ p から誤る & & なし & なし \\
\hline 8 & M & 3 & 自主来院 & 吃音 & VIQ 94, PIQ 135, IQ 117 & & あり & なし \\
\hline 9 & $\mathrm{~F}$ & 5 & $\begin{array}{l}\text { 紹介 } \\
\text { (知的障害施設) }\end{array}$ & $\begin{array}{l}\text { 発達障害 } \\
\text { (アスペルガー) }\end{array}$ & VIQ 68, PIQ 98, IQ 79 & & あり & あり \\
\hline 10 & M & 3 & 診察時医師指摘 & 吃音 & VIQ 77, $\mathrm{PIQ} 90$, IQ 80 & & あり & なし \\
\hline 11 & M & 3 & 診察時医師指摘 & $\begin{array}{l}\text { 構音障害· } \\
\text { 言語発達遅滞 }\end{array}$ & VIQ 93, PIQ 86, IQ 87 & $\mathrm{t} / \mathrm{s}, \mathrm{tJ} / \mathrm{s}$ & あり & なし \\
\hline 12 & $\mathrm{~F}$ & 5 & 診察時医師指摘 & $\begin{array}{l}\text { 構音障害· } \\
\text { 言語発達遅滞 }\end{array}$ & VIQ 74, PIQ 101, IQ 85 & $\begin{array}{l}\mathrm{d} / \mathrm{g}, \quad \mathrm{t} \int / \mathrm{k}, \quad \mathrm{t} \int / \mathrm{s}, \quad \mathrm{t} \int / \mathrm{ts}, \\
\mathrm{d} 3 / \mathrm{d} z\end{array}$ & なし & なし \\
\hline 13 & M & 3 & $\begin{array}{l}\text { 紹介 } \\
\text { (児童相談所) }\end{array}$ & $\begin{array}{l}\text { 構音障害· } \\
\text { 言語発達遅滞 }\end{array}$ & VIQ 94, PIQ 87, IQ 89 & t/k *歪み $(+)$ & あり & なし \\
\hline 14 & M & 3 & 乳幼児健診 & 吃音 & $\begin{array}{l}\text { 新版 K 式 C-A 102，L-S 90, } \\
\text { 全領域 } 96\end{array}$ & & あり & なし \\
\hline
\end{tabular}

WPPSI：WPPSI 知能検査, IQ：全 IQ, VIQ：言語性 IQ, PIQ：動作性 IQ, PVT：絵画語彙検査, VA：語彙年齢, SS：評価点（10 が平均值), 新版 $\mathrm{K}$ 式: 新版 $\mathrm{K}$ 式発達検査, C-A : 認知 - 適応領域発達指数, L-S : 言語・社会領域発達指数, 全領域: 全領域発達 指数

いたが医療機関を受診させていなかった。また，以前 より言語訓練目的にて当院に通院中もしくは通院既往 のある7 児の保護者についても，6児が当院受診前に 子供の言語異常に気づいていたが，医療機関を受診さ せていたのは 1 児のみであり，他の 5 児は乳幼児健診 や児童相談所からの紹介, 医師診察時の指摘により受 診していた（表 1).

\section{4. 言語の精密検査結果}

健診で言語障害と診断されてわれわれの診療所を受 診した 14 児のうち, 精密検査の結果, 異常なしと診 断されたのは 1 児のみであった. 13 児の言語病理学 的診断名は, 機能性構音障害が 1 児, 言語発達遅滞を 伴った構音障害が 6 児, 知的障害が 1 児, 発達障害が 2 児（アスペルガー症候群疑い 1 児, 学習障害 1 児), 吃音 3 児であった（表 1 ).

このうち, 今回の健診で新たに言語障害の診断を受 けた 7 児のうち, 異常なしと診断された 1 児を除く 6 児（表の症例 $1 \sim 6$ ）の言語精査の結果は以下のとお
りである, 症例 1 は健診時応答に時間がかかり, 緩慢 であった. WPPSI 知能検査において PIQ（動作性 IQ）104 に対して VIQ（言語性 IQ）79 と大きな差が あり，下位検査項目の評価点にばらつきが見られたた め, 発達障害（学習障害）と診断した。症例 2 は $\mathrm{k} \rightarrow \mathrm{t} \int へ の$ 置換例であるが, 検査結果は正常範囲で あり機能性構音障害と診断した。症例 5 は WPPSI 知 能検査でIQ 64 であり，知的障害に伴う言語障害と診 断した，症例 3，4，6 は種々の構音障害を示している が，いずれも獲得語彙数が少なく、VIQが標準より 低值を示したため, 構音障害・言語発達遅滞と診断し た。

\section{考察}

\section{1. 言語異常の有所見率}

現在行われている小中学校の耳鼻咽喉科学校健診は 重点検診であり, 全員を検診するのは小学校 2 年生, 5 年生, 中学校 1 年生に限られている。他の学年は問 
診票もしくは前年度の検診で有所見となった者のみを 対象としている，そこで本研究では，対象児全員を検 診でき就学前の最後のスクリーニングである就学時健 診を対象に調査を行った。その結果，医師の検診によ り 13.4\%の览が言語異常の所見ありと診断された。こ れは耳鼻咽喉科疾病の有所見率のなかでアレルギー性 鼻炎に次いで 2 番目に高い有所見率であった。

著者らは 2001 年に就学時健診の 286 名を対象に類 似の調査を行ったが，その際にも言語異常の有所見率 は $11.5 \%$ と今回に近い值であった かには就学時健診に扔ける言語異常の有所見率につい て，比較できる報告は発見できなかった，

就学後の小学校における定期健康診断での有所見率 については，以下の報告がある。日本耳鼻咽喉科学会 学校保健委員会の全国定点調査（以下全国定点調査） における平成 12 年度 (2000 年) から平成 16 年度 (2004 年）までの耳鼻咽喉科疾病の有所見率の平均值では, アレルギー性鼻炎の割合が最も多く, 次いで耳垢栓塞, 慢性鼻炎の順に高值を示した，今回のわれわれの健診 とは，言語異常と音声異常の有所見率を除けば，同様 の傾向を示した. 定点調査での言語異常の有所見率は, 小学校 1 年生 $0.17 \%, 2$ 年生 $0.08 \%, 3$ 年生 $0.04 \%, 4$ 年生 $0.03 \%, 5$ 年生 $0.02 \%, 6$ 年生 $0.03 \%$ であり, 口 腔の異常に次ぎ 2 番目に低值であったと報告されてい る3)。また, 酒向らが行った平成 18 年度（2006 年） の川崎市の小学生 32,689 人, 中学生 8,191 人を対象と した耳鼻咽喉科定期健康診断での言語異常有所見率 は,いずれも $0 \%$ と報告されている7).さらに橋本らは, 平成 18 年度の札幌市の小中学校の耳鼻咽喉科学校健 診（対象小学生 95,082 名, 中学校 47,724 名) で, 音 声異常と言語異常を併せた数字では小学校が $0.07 \%$, 中学校では 0.05\%であったと報告している8 ${ }^{8)}$.

本研究では, 健診対象児の全例に対して耳鼻咽喉科 医が「学校保健での音声言語障害の検診法」2) を用い て言語障害の検診を行うことで，記載されている 10 〜 20\%という数值に近い言語障害の有所見率が得られ た，従来の学校健診の調査報告では言語異常の有所見 率がいずれも $1 \%$ 以下であり, 学校健診においてこの 検診法がうまく活用されていない可能性が示唆され た。

\section{2. 言語聴覚士による言語スクリーニングの有用性}

健診において「学校保健での音声言語障害の検診法」 を活用するためには，健診の実施にかかる時間の短縮 が必要である。本研究では, 健診対象児全例に対して あらかじめ言語聴覚士が言語スクリーニングを実施し
た。その結果, 言語異常の所見ありと評価した 46 児 のうち, その後の耳鼻咽喉科医による検診で言語障害 と診断されたのは 31 児であった。一方, 言語聴覚士 が事前の言語スクリーニングで言語異常の所見なしと 評価した児のなかで，医師が検診で言語障害と診断し た児はいなかった。すなわち，本研究における言語聴 覚士による事前の言語スクリーニングが言語異常を検 出する感度は $66 \%$ であり, 特異度は 100\%であった。 特異度が100\%であったことから，耳鼻咽喉科医の検 診前に言語聴覚士による言語スクリーニングを行え ば，所見ありと評価された坚を重点的に検診すること ができ, 耳鼻咽喉科医が「学校保健での音声言語障害 の検診法」をスムーズに実施することができると考え られた。しかし，現在このような医師と言語聴覚士が 役割を分担した言語聴覚士による検診前の言語スク リーニングは，他の地域では全く行われていないのが 現状である。今後このような健診業務に言語聴覚士が 参画していくためには，客観性のある評価を行うこと ができ， 1 人 1 人の児について医師の判定に役立つ情 報を的確に伝える資質が求められる。

\section{3．言語障害に対する保護者の気づき}

健診で言語障害と診断された 14 児のうち， 7 児 （45\%）が言語の精査目的で著者の所属する診療所を 受診した。健診を行った地域で言語障害に対応できる 精査医療機関は当診療所だけであることを考えると， 健診で言語障害と診断された児の約半数の保護者が, 児に精密検查を受けさせていない可能性がある。また， 今回の健診で初めて言語障害を指摘され，われわれの 診療所を受診した 7 児の保護者のうち，3名は子供の 言語異常に気づいておらず，4名は気づいていたが医 療機関を受診させていなかった。

橋本らが学校健診について耳鼻咽喉科医へ行った解 答選択式のアンケート調査によると，「音声異常・言 語異常が学校健診の診断項目になっていることについ て」という質問の回答では,「スクリーニングなので 厳密に考える必要がない」が 25 名 (52.1\%) ある一方 で,「家庭や教室で発見できるので検診項目から除外 すべき」との意見が 19 名（39.6\%）見られた。この結 果を受け,「音声言語の異常は耳鼻咽喉科医による治 療や管理が必要であることや早期発見と早期治療ある いは早期支援開始が重要であること」を認めたうえで, 「実際には言語発達が進む幼児期にほとんどが家庭生 活のなかですでに家族が気づいて, 学校側と相談し, 指導や助言が行われているために，学校健診における 耳鼻咽喉科医の音声・言語障害の診断はすでに重要性 
が薄れているのではないか」と述べている8). しかし， 本研究の結果から, 診療所を受診した保護者のうち 3 名は子供の言語異常に気づいていなかったことから, 就学時健診に扔ける言語異常検診の意義があると考え る.

一方，4名は子供の言語異常に気づいていても医療 機関を受診させておらず，言語障害をもつ览が医療機 関や教育機関に扔いて十分な支援を受けられていない 可能性が示唆された，言語障害児を医療機関を受診さ せない理由として, 保護者が不安から子供の言語障害 を認めたくない気持ち, 保護者の言語障害に対する問 題意識の希薄さ，言語発達の遅れに気づきにくい現代 の育児環境などが考えられた。このような保護者に とって, 健診は言語障害をもつ子供の医療機関への受 診を促す機会となっていると考えられた。また，今回 健診を行った地域には通級指導教室はなかった。しか し, 隣接地域の小学校に併設している通級指導教室に 通うことも可能であるため, 保護者に対して医療機関 や教育機関を通して啓蒙を行っていく必要があると考 えられた。

\section{4. 言語の精密検査結果}

就学時健診で言語障害と診断した 31 児のうち, 著 者らの施設を受診し, 言語の精密検査を行ったのは 14 児であった。このうち, 今回初めて言語の精密精 查を行った 7 児のうち 6 児に言語訓練が必要であった。
このことから，健診はスクリーニングの場であり，時 間に限りはあるものの言語障害の検診を適切に実施 し，少しでも異常が疑われた览は所見ありとすること で，それまでに診断されていなかった言語障害児を発 見して言語訓練の機会を与えることができると考えら れた。

\section{文献}

1）日本学校保健会：児童生徒の健康診断マニュアル，1995.

2) 日本耳鼻咽诶科学会学校保健委員会：学校保健での音声言 語障害の検診法, 1999.

3) 日本耳鼻咽喉科学会学校保健委員会: 平成 12 年 平成 16 年度耳鼻咽唉科健康診断の全国定点調查, 2005.

4）田口恒夫, 他：新訂版ことばのテスト絵本, 日本文化科学 社, 東京, 1968.

5) 日本学校保健会：就学時の健康診断マニュアル，2002.

6）留守 幸, 他：就学時健診に言語聴覚士がかかわって. 小 児耳鼻咽唉科, $124: 38-41,2003$.

7）酒向 司，他：川崎市に扔ける耳鼻咽喉科定期健康診断の 疾患別統計について。川崎市医師会医学会誌, 24:71-76, 2007.

8）橋本紘治, 他：小中学校に㧍ける音声言語異常の現状と問 題点. 北海道医報, $1068: 5-7,2007$.

別刷請求先: $=779-3233$ 德島県名西郡石井町石井字石井 635-29

宇高耳鼻咽喉科医院

森実加奈 